University of St. Thomas, Minnesota

UST Research Online

Philosophy Faculty Publications

Philosophy

2010

The Possibility Principle And The Truthmakers For Modal Truths

Timothy J. Pawl

University of St. Thomas, Minnesota, pawl8866@stthomas.edu

Follow this and additional works at: https://ir.stthomas.edu/cas_phil_pub

Part of the Philosophy Commons

This Article is brought to you for free and open access by the Philosophy at UST Research Online. It has been accepted for inclusion in Philosophy Faculty Publications by an authorized administrator of UST Research Online. For more information, please contact asle4660@stthomas.edu. 


\title{
THE POSSIBILITY PRINCIPLE AND THE TRUTHMAKERS FOR MODAL TRUTHS
}

\author{
Timothy Pawl
}

\begin{abstract}
A necessary part of David Armstrong's account of truthmakers for modal truths is his Possibility principle: any truthmaker for a contingent truth is also a truthmaker for the possibility of the complement of that contingent truth (if $\mathrm{T}$ makes $p$ true and $p$ is contingent, then $\mathrm{T}$ makes $\diamond \sim p$ true). I criticize Armstrong's Possibility principle for two reasons. First, his argument for the Possibility principle both relies on an unwarranted generalization and vitiates his desire for relevant truthmakers. His argument undercuts relevant truthmakers by entailing that each contingent being is a truthmaker for all modal truths. Second, even if the argument seems successful, the Possibility principle is subject to counterexamples. Armstrong's being composed of more than fifty atoms makes it true that something composed of more than fifty atoms exists and that truth is contingent, but his being composed of more than fifty atoms does not make it true that it is possible that it is not the case that something composed of more than fifty atoms exists.
\end{abstract}

David Armstrong is the most well-known proponent of truthmaker theory, and his book, Truth and Truthmakers, is the most well-known defence of it. In this book, Armstrong provides his Possibility principle: any truthmaker for a contingent truth is also a truthmaker for the possibility of the complement of that contingent truth (if T makes $p$ true and $p$ is contingent, then $T$ makes $\diamond \sim p$ true), a principle with which his account of truthmakers for modal truths stands or falls. And, while the book has received much critical attention, this particular principle, which is so important to his work, has received relatively little. ${ }^{1}$ Furthermore, what attention it has received has been, in all but one problematic case, paid to the argument Armstrong gives for the principle, and not to whether the principle itself is true or false. ${ }^{2}$ Armstrong has conceded, in the pages of this very journal, that his argument in Truth and Truthmakers was 'marred by a very bad mistake' [2006b: 245]

\footnotetext{
${ }^{1}$ Cameron [2005], McDaniel [2005], Mumford [2005] and Tallant [2005] all provide careful reviews of the book, but none mentions the Possibility principle. Alward [2004: 76-7] and Bostock [2005: 369] briefly discuss the principle without calling it into question; Hochberg [2006: 187-8] doesn't argue that the Possibility principle is false, but he does claim that Armstrong does not go far enough in showing how the intrinsicality of contingency should be understood in his argument and that Armstrong must, in the end, appeal to a fundamentally modal entity in his account of truthmakers for modal truths; Keller [2007] argues clearly that Armstrong's [2004] argument for the Possibility principle is flawed, but does not provide an argument that the principle itself is false; and Simons [2005: 254] claims that the argument is invalid and that the Possibility principle is implausible, but offers no reasons for thinking the principle implausible.

${ }^{2}$ Kalhat [2008] provides the one extant argument for the falsity of the Possibility principle. It is problematic because it, like Armstrong's [2007: 103] argument, has de re-de dicto confusions. I will discuss this problem later as my second smallish point in $\S 3$.
} 
and that he 'certainly made a dreadful hash of arguing' for it [2005: 271], but he also says that he still thinks the Possibility principle is defensible. He has since given another argument for the Possibility principle, which has yet to be discussed in the literature [2007: 103]. In this paper, I criticize that new argument, then I go on to argue that the Possibility principle is false.

Armstrong criticizes both David Lewis and Alvin Plantinga for ontological extravagance in his book, Truth and Truthmakers. He writes, after reference to Lewis and Plantinga:

It seems to me very surprising that so many good philosophers consider that huge metaphysical commitments must be made in order to give an account of these truths [of mere possibility].

[2004: 83]

He goes on to say that 'these philosophers are bringing giants to do a boy's work' [loc. cit.].

The giants to whom Armstrong refers are well known. ${ }^{3}$ Armstrong takes Plantinga to seek the ontological grounding of modal truths in abstract possible worlds and haecceities. Lewis argues that at least some modal truths are made true by concrete, unactual worlds and their parts. ${ }^{4}$ It would be better, all else being equal, if we could ground modal truths without recourse to necessarily existing haecceities or unactual, concrete worlds. Armstrong has attempted to provide truthmakers for modal truths without such ontological bloating. To cure this distention he prescribes the Possibility principle.

If Armstrong's account of truthmakers for modal truths were successful, it would be of no small significance. For, if successful, it removes a strong incentive to carry the heavy ontological burden that Plantinga and Lewis hold. ${ }^{5}$ If Armstrong can show that we can ground modal truths without the costs associated with Lewis and Plantinga's ontologies, he has done a great service to modal metaphysics. He will have, to use his own words, splashed 'cold water on the need for the wildly ambitious truthmakers that have been proposed by a number of contemporary metaphysicians' [2004: 85].

I criticize Armstrong's attempted ontological grounding for modal truths on two grounds. First, I claim that his argument for the Possibility principle is weak. As presented in Truth and Truthmakers, it is unsound. Armstrong has recognized this infelicity and attempted to amend it. His emendation, however, has two problems of its own. It requires an unwarranted generalization and it runs counter to Armstrong's stated desire for relevant truthmakers. Second, even if the argument seems successful, the Possibility principle is subject to counterexamples. Armstrong makes it true that something composed of more than fifty atoms exists and that truth is contingent, but he does not make it true that it is possible that nothing composed of more

\footnotetext{
${ }^{3}$ To see the accounts that elicit this charge of extravagance, see Plantinga [1974] and Lewis [2001b, especially $\S 1]$.

${ }_{4}^{4}$ Lewis [2001b], especially $\S 1.8$. This isn't the whole story for Lewis. The actual world and its parts make some modal truths true as well. The point here, though, is that Lewis needs unactual worlds and their parts in addition to the actual world and its parts.

${ }^{5}$ I say $a$ strong incentive since each thinker claims that other benefits accrue from his preferred ontology.
} 
than fifty atoms exists. I don't think Armstrong does the boy's work he sets out to do. And that may be because one really needs giants for it.

\section{Armstrong's Truthmakers for Truths of Possibility}

Truths of possibility can be distinguished into truths of possibility that are also truths of actuality and truths of mere possibility. A truth, $p$, is a truth of mere possibility if and only if $\diamond p$ is true and $p$ is false (and, of course, the first sort of truth of possibility mentioned obtains if and only if $\diamond p$ and $p$ are both true). Armstrong thinks that truths of mere possibility are the difficult truths of possibility to ground. For the other sort of truths - call them truths of actual possibility-Armstrong claims that the very thing that makes $p$ true also makes $\diamond p$ true.

To ground truths of mere possibility, he provides his Possibility principle. In Truth and Truthmakers, Armstrong offers the following argument for the Possibility principle. Suppose T makes $p$ true. Suppose $p$ is contingent (if it isn't contingent, we aren't talking about truths of mere possibility anymore). Given that $p$ is contingent, it follows that it is possible that not-p. Armstrong claims (mistakenly, as we will see below) that since T makes $p$ true, and $p$ entails that it is possible that not- $p$, it seems that T should make it true that it is possible that not- $p$. Thus, if $\mathrm{T}$ makes $p$ true and $p$ is contingent, then $\mathrm{T}$ makes $\diamond \sim p$ true. 'At a stroke', says Armstrong, 'we have removed the need for any truthmakers for truths of "mere possibility" except the truthmakers for contingent truths' [2004: 84].

Armstrong formalizes his argument as follows, where the arrow stands for the cross-categorical necessitation that holds between truthmakers and truthbearers. Armstrong writes [loc. cit.]:

1. $(\mathrm{T} \rightarrow p)$ (assumed)

2. that $p$ is contingent (assumed)

3. $\quad p$ entails that it is possible that not-p (from 2 and the nature of the contingency of propositions)

Thus,

4. $\mathrm{T} \rightarrow$ that it is possible that not- $p^{6} \quad$ (by 1,3 and the Entailment principle)

The justification for the concluding inference requires explanation. Armstrong relies on

The Entailment principle: If $\mathrm{T}$ makes true that $p$ and that $p$ entails* that $q$, then $\mathrm{T}$ makes true that $q$.

${ }^{6}$ I've changed the denotation of propositions in his argument to match the style I use in this article. Armstrong uses angled brackets $(<\mathrm{p}>$ ) to denote propositions, whereas I italicize to denote propositions $(p)$. Otherwise, this is how he presents his argument. One might notice that in this argument for the Possibility principle Armstrong writes of $p$ and the possibility of $n o t-p$, whereas in the Possibility principle itself he writes of $n o t-p$ and the possibility of $p$. This change has no effect on the logic of the argument or the viability of my coming criticisms. 
Armstrong writes 'entails*' rather than 'entails' because he doesn't intend the Entailment principle to range over all entailments. If the Entailment principle were to range over all entailments, then any thing would be a truthmaker for every necessary truth. Armstrong makes it true that Armstrong exists. That Armstrong exists logically entails that, necessarily, $2+2=4$. Armstrong, however, is not a truthmaker for that mathematical truth. So there must be some way to rein in the entailment* in the Entailment principle so that we have 'relevant truthmakers' [2004: 11]. Armstrong doesn't provide a way for doing this. He writes, 'I will simply assume that something is available' [loc. cit.]. In the following I assume with him that there is some way to rein in entailment appropriately. If there ends up being no way to do so, then the argument against Armstrong's truthmakers for modal truths would end here, since the last step in his argument requires the Entailment principle. Finally, notice that since Armstrong puts the Entailment principle to work in justifying the move from 3 to 4 , the entailment in 3 must be understood as entailment*. Otherwise, the Entailment principle would not be applicable to 3 .

\section{A 'Sad Blunder'}

There is a problem with Armstrong's argument for the Possibility principle. Armstrong has recently realized this problem in his argument, calling it a 'sad blunder' [2007: 101]. At a conference entitled Truths and Truthmakers he said,

I thought that all we need do is to consider some truthmaker of a contingent truth, and then use the Entailment principle to show that this truthmaker was also a truthmaker for the entailed mere possibility. This is clearly wrong. To get an entailment we need that the truth is a contingent one, and this means that we need, not a truthmaker for $p$, but a truthmaker for the truth $p$ is contingent. ${ }^{7}$

[2007: 101]

This is all he says before moving on to provide a new argument for the Possibility principle, which I will discuss later. The quotation is opaque and could use some elucidation. Here is what I take Armstrong to mean.

That $p$ is contingent entails that it is possible that not- $p$. After all, $p$ is contingent if and only if both $p$ and $\sim p$ are possible. Given that $p$ is contingent, it follows straightforwardly that it is possible that not-p. This is not what 3 says, however. It doesn't say,

That $p$ is contingent entails* that it is possible that not-p;

\footnotetext{
${ }^{7}$ Again, I've modified the way in which propositions are referred to in this quotation. Rather than using Armstrong's brackets, I've continued to use italics to denote propositions.
} 
rather, it says,

(B) $\quad p$ entails* that it is possible that not-p.

This, I think, is where the problem for the argument begins. (A) is true, but I see no reason to affirm $(\mathrm{B})$.

One reason Armstrong may have had in support of (B) is that 2 already tells us that $p$ is contingent. So (B) isn't the obviously false claim that any proposition $p$ entails* that its negation is possible. Rather, it is the much more modest claim that any contingent proposition entails* that its negation is possible. (B), in the light of $p$ 's contingency, provides a legitimate entailment.

This suggested support for (B) doesn't work. For $p$ alone still doesn't entail* $^{*}$ the possibility of its negation, even if it is contingent. $P$, together with that $p$ is contingent, entails* that the negation of $p$ is possible. But $p$ alone doesn't entail* that the negation of $p$ is possible, and thus this suggested support is no support of (B) at all, since (B) requires that $p$ entail* that it is possible that not-p.

Another way to see this is to start a proof with $p$ and attempt to prove that $\diamond \sim p$ without recourse to a premise that says that $p$ is contingent. It can't be done. If one makes recourse to a premise that $p$ is contingent, then $p$ alone doesn't entail* $\diamond \sim p$. So Armstrong's premise 3-that $p$ entails that it is possible that not- $p$ - is false. I take it that this is what Armstrong had in mind when he called this step in his argument a sad blunder, and I think he is right to have found this objection decisive. ${ }^{8}$

\section{Armstrong's New Argument for the Possibility Principle}

After voicing this objection to his argument for the Possibility principle, he goes on to provide another argument for it. He argues that it is plausible that if $\mathrm{T}$ is a truthmaker for a contingent truth $p$, then $\mathrm{T}$ is a truthmaker for that $p$ is contingent. If he is right, then he has a justification for the Possibility principle. For consider: that $p$ is contingent entails* that it is possible that not-p. So, by the Entailment principle, if $\mathrm{T}$ is a truthmaker for that $p$ is contingent then $\mathrm{T}$ is a truthmaker for that it is possible that not-p. And if Armstrong is right that if $\mathrm{T}$ is a truthmaker for a contingent truth $p$, then $\mathrm{T}$ is a truthmaker for that $p$ is contingent, then by a hypothetical syllogism, if $\mathrm{T}$ is a truthmaker for a contingent truth $p$, then $\mathrm{T}$ is a truthmaker for that it is possible that not-p-which is a restatement of the Possibility principle.

He argues as follows, writing of a contingent truth $p$ and its truthmaker T:

Now consider some contingent being in nature. It might not have existed. But can we not add: its existence or non-existence as a contingent being is not logically dependent on the existence or non-existence of any further contingent being. A counterfactual holds: it might have been there, but unaccompanied

\footnotetext{
${ }^{8}$ For more discussion of the problems with Armstrong's [2004] argument, see Keller [2007].
} 
[N.B. Armstrong assumes that all beings are contingent]. And if so, must not the truthmaker for the contingency of its existence be itself, T? So if $\mathrm{T}$ is a truthmaker for some contingent truth $p$, then it will also be a truthmaker for that $p$ is contingent.

[2007: 103]

Armstrong asks us to consider some contingent being in nature, T. T could have existed without anything else existing; it could have been alone in the world. If it were the case that $\mathrm{T}$ exists but is alone in the world, it would still be true that it is contingent that T exists. T's solitude doesn't make it exist necessarily; also, remember, Armstrong asks us to consider a contingent being. So that it is contingent that T exists is true. But, since it is alone, the only thing in that world to do the truthmaking for the truth that it is contingent that $T$ exists is $\mathrm{T}$, that very lonely thing. And given that modal truths have truthmakers, which Armstrong assumes, something must make it true that it is contingent that $T$ exists. So $\mathrm{T}$ is a truthmaker for that it is contingent that $T$ exists. This argument isn't applicable only to T. Any other contingent being, if it were alone in the world, would still exist contingently. By generalizing we arrive at the conclusion that if $\mathrm{T}$ is a truthmaker for some contingent truth $p$, it is also a truthmaker for that $p$ is contingent (I think this is an unwarranted generalization, as I shall argue in what follows). The rest of the argument should be easy to see. T makes some contingent truth, $p$, true. If $\mathrm{T}$ makes $p$ true, it is also a truthmaker for that $p$ is contingent (given the preceding argument). So $\mathrm{T}$ is a truthmaker for that $p$ is contingent. Furthermore, as (A) said above, that $p$ is contingent entails* that $\sim p$ is possible. So, again, by the Entailment principle, $\mathrm{T}$ is a truthmaker for that $\sim p$ is possible. Hence we arrive at the Possibility principle: If T makes $p$ true and $p$ is contingent, then $\mathrm{T}$ makes $\diamond \sim p$ true.

I will make two smallish points concerning this argument before I go on to provide two objections to it. First, I don't think that Armstrong can say that T's existence or non-existence is not logically dependent on the existence or non-existence of any further contingent being. I take it that Armstrong understands the logical dependence of object $x$ on object $y$ to mean that $x$ couldn't exist if $y$ didn't exist. Consider, though, for instance, the state of affairs of Armstrong's being male. Isn't that state of affairs logically dependent on Armstrong? Armstrong thinks that states of affairs are non-mereologically composed. ${ }^{9}$ In this case, the state of affairs of Armstrong's being male is non-mereologically composed of Armstrong and maleness. How could such a state of affairs exist and Armstrong not exist? This should give us pause in affirming Armstrong's claim that anything can exist unaccompanied. We should remember, however, that unaccompanied existence is an important part of his argument, since he wants to claim that the lonely thing, $\mathrm{T}$, is a truthmaker for that $T$ is contingent. The claim that $\mathrm{T}$ is the truthmaker for that $T$ is contingent becomes plausible if $\mathrm{T}$ can exist alone, since, as Armstrong assumes, every truth needs a truthmaker, and

\footnotetext{
${ }^{9}$ Armstrong [1997], especially chapter 8. Perhaps you wonder what sort of beast non-mereological constitution could be. Isn't mereology the study of constitution? David Lewis, in more than one place, expresses his perplexity at Armstrong's notion of non-mereological constitution; cf. Lewis [2005: 34].
} 
there is nothing but $\mathrm{T}$ to do the truthmaking in the lonely world. If $\mathrm{T}$ can't be alone, however, then there could (at least epistemically) be something else there to do the truthmaking for that $T$ is contingent. And hence the support that the lonely thing argument lends to the claim that $\mathrm{T}$ is the truthmaker for that $T$ is contingent collapses.

My second smallish point has to do with Armstrong's use of language. $\mathrm{He}$ writes: 'must not the truthmaker for the contingency of [T's] existence be itself, T?' Strictly speaking, the contingency of T's existence doesn't stand in need of a truthmaker, since it is not a proposition. What Armstrong needs here is that $\mathrm{T}$ makes that it is contingent that $T$ exists true. One should note that this claim needs to be a de dicto, not de re modal truth. If it were a de re modal claim, it would not have the right form. Armstrong needs $\mathrm{T}$ to make true $\diamond$ that $T$ exists $\& \diamond \sim$ that $T$ exists, not that $T$ exists contingently. ${ }^{10}$ The former truth is a modal truth of the right form with obvious relevance to the Possibility principle. The latter is not a truth of actual or mere possibility, as defined above.

Javier Kalhat [2008: 172], who provides the only argument for the falsity of the Possibility principle that I've found in print, follows Armstrong's lead here and uses de re modal propositions in his argument. His example of an instance of the Possibility principle is that the truthmaker for that Armstrong exists is also the truthmaker for the proposition Armstrong is possibly nonexistent. ${ }^{11}$ Strictly speaking, this proposition is of the wrong form to be relevant to the Possibility principle. In my discussion of the argument, I will assume that when Armstrong says that $\mathrm{T}$ is a truthmaker for the contingency of its existence, he means that $\mathrm{T}$ makes $\diamond$ that $T$ exists \& $\diamond \sim$ that $T$ exists true. Now for the two objections to this argument.

\section{Two Problems with the New Argument}

There are two serious problems with the argument: it makes an unwarranted generalization, and it belies Armstrong's desire for relevant truthmakers.

To see the first problem, that the argument requires an unwarranted generalization, consider the last two sentences of the above quotation. By the penultimate sentence, Armstrong takes himself to have shown that the truthmaker for the contingency of T's existence is T itself. That is, he takes himself to have shown that $\mathrm{T}$ makes it true that it is contingent that T exists. Grant him that particular example. From here he concludes to the ultimate sentence: 'if $\mathrm{T}$ is a truthmaker for some contingent truth $p$, then it will also be a truthmaker for that $p$ is contingent'. That does not follow. The penultimate sentence, provided the argument up to it is sound, secures

\footnotetext{
${ }^{10}$ Here and elsewhere in this article I affix the box $(\square)$ and diamond $(\diamond)$ to propositions to represent modal propositions. Since I represent propositions by italicizing that-clauses, I've affixed the modal operators to the that-clauses, rather than removing the that from the that-clause (e.g., $\diamond T$ exists rather than $\diamond$ that $T$ exists), as is sometimes done.

${ }^{11}$ See also Kalhat [2008: 174]: 'I argued that the Possibility Principle is false, since the truthmaker for, say, the proposition <Armstrong exists > cannot plausibly be taken to be also a truthmaker for the possibility of his non-existence'. Kalhat goes on to provide an additional argument for the falsity of the Possibility principle which I will not discuss here: the Possibility principle requires an application of the Entailment principle, and the Entailment principle is false, so the Possibility principle must be false as well.
} 
truthmakers for modal truths about the existence of contingent beings. It does not, however, provide truthmakers for all modal truths, as Armstrong needs it to. Just because $\mathrm{T}$ is a truthmaker for that it is contingent that $T$ exists (again, granting that it is), it does not follow that if $\mathrm{T}$ is a truthmaker for any contingent truth, $p$, then $\mathrm{T}$ is also a truthmaker for that $p$ is contingent. This is an illicit generalization. We need an argument that shows that we can generalize from the smaller set of truths to the larger set.

It may be that truths about the contingency of an object's existence are made true by the object itself. For instance, Armstrong himself (or perhaps his nature) may be a truthmaker for the truth that it is contingent that Armstrong exists, though I have my doubts. ${ }^{12}$ There are, however, other modal truths that don't fare well on this argument. What of truths that aren't about the contingency of an object's existence? The state of affairs of Armstrong's being composed of $N$ atoms, where $N$ is greater than fifty, makes it true that something is composed of more than fifty atoms. Does such a state of affairs thus make it true that it is contingent that something is composed of more than fifty atoms? It doesn't seem to. Saying 'It is contingent that $p$ ' is shorthand for 'It is possible that $p$ and it is possible that it not be the case that $p$ '. Does that particular state of affairs really make it true that it is possible that something is composed of more than fifty atoms and it is possible that it is not the case that something is composed of more than fifty atoms? Suppose $N$ is ten billion. Then the state of affairs, Armstrong's being composed of ten billion atoms, is a truthmaker for the truth that it is possible that it is not the case that something is composed of more than fifty atoms. But this is false! Armstrong's being composed of ten billion atoms has nothing to do with whether or not it could be the case that nothing is composed of more than fifty atoms. At the very least, it is not clear that Armstrong's being composed of ten billion atoms is a truthmaker for that claim; we need an argument for this. So the generalization is hasty: Armstrong generalizes from a claim that might appear plausible to somethat if $\mathrm{T}$ contingently exists, then $\mathrm{T}$ is a truthmaker for that it is contingent that $T$ exist-to a claim that allows for counterexamples - that if $\mathrm{T}$ is a truthmaker for $p$ and $p$ is contingent, then $\mathrm{T}$ is a truthmaker for that $p$ is contingent.

Now consider a second problem for Armstrong's new argument- the problem of relevance. Armstrong desires relevant truthmakers for all truths. He writes [2004: 85; his emphasis]:

We may also notice how attractive it is to hold that every contingent truth, not merely every positive contingent truth, has a truthmaker. Given this, the Entailment principle can then give the attractive result, attractive for those looking for system and coherence, that these simple but relevant truthmakers exist for every 'mere possibility'.

\footnotetext{
${ }^{12}$ What about him does the work of making it true that it is contingent that Armstrong exists? And couldn't it be the case that it only does the work because of something that is true of all beings of his type? Couldn't it be that he is contingent only because he is a human (which he makes true) and that all humans are contingent (which something besides Armstrong alone makes true, or nothing at all makes true)? This suggestion seems plausible as well.
} 
Armstrong's aim is to provide relevant truthmakers for modal truths. Providing relevant truthmakers for truths should be the aim of any truthmaker theorist, but especially one attempting to find truthmakers for modal truths. If relevance weren't a necessary condition for a viable truthmaker theory, any thing would be a truthmaker for every modal truth, as I pointed out in the discussion of the Entailment principle. Armstrong's new argument for the Possibility principle belies this desire for relevant truthmakers. $^{13}$

Consider these lines from Armstrong's new argument:

[I]t might have been there, but unaccompanied. And if so, must not the truthmaker for the contingency of its existence be itself, T?

Why the 'must'? It looks to me that the truthmaker must be T itself because (a) it is true that T exists contingently, and (b) there must be some existing thing to make it true. In that world, the world where $T$ exists but is unaccompanied, $\mathrm{T}$ is the only object around to do the work of truthmaking, so it must be what makes it true that T exists contingently.

This leads to difficulties for Armstrong because he thinks (as most philosophers writing on modality do) that truths of possibility are themselves necessary. ${ }^{14} \mathrm{He}$ writes, for instance, '[I]f $p$ is contingent, it is a necessary truth that it is contingent' [2004: 85]. And again, 'Most philosophers, including myself, would take it is possible that not-p to be a necessary truth' [2004: 84]. So every modal truth-being necessary - is true in the world where $\mathrm{T}$ exists unaccompanied - the world Armstrong posits for his argument - but $\mathrm{T}$ is the only thing that exists in that world. Since Armstrong affirms truthmaker Maximalism - that all truths have truthmakers - and affirms that it is possible that $\mathrm{T}$ exist unaccompanied, $\mathrm{T}$ then must be the truthmaker for all modal truths!

Surely this is a sin against the relevance requirement for truthmakers. Whatever contingent being of nature $\mathrm{T}$ is, it can't be a relevant truthmaker for all modal truths. It can't be a relevant truthmaker for that, necessarily, $2+2=4$ and that it is possible that there be three more men with brown hair in Dyer, Indiana and that it is possible that everyone have one more friend and that it is possible that David Armstrong is an astronaut and that it is possible that Neil Armstrong is a philosopher. So Armstrong's argument undercuts a desideratum of his truthmaking theory: that truthmakers be relevant to the truths they make true.

Either these modal truths have truthmakers or they don't. If they don't have truthmakers, then Armstrong's truthmaker Maximalism, a central pillar of his work, is false. If these truths do have truthmakers, then $\mathrm{T}$ is their truthmaker, since, as Armstrong assumes for argument, $\mathrm{T}$ alone exists in this world. But then these truths do not have relevant truthmakers. Armstrong's aim with the Possibility principle is to provide relevant truthmakers. So either Armstrong's Maximalism is false or his desire for

\footnotetext{
${ }^{13}$ Another way of stating the same desideratum is that truthbearers must be about the truthmakers that make them true. See, for instance, Merricks [2007: 28-34] and Lewis [2005: 25].

${ }^{14}$ That modal truths are themselves necessarily true follows from the S5 system.
} 
relevant truthmakers is unfulfilled. Either way, Armstrong's new argument for the Possibility principle goes contrary to his truthmaker theory.

\section{Counterexamples to the Possibility Principle}

Finally, even if my arguments against the Possibility principle fail, we should still reject it since it is subject to counterexamples. Recall the earlier example concerning the number of atoms that compose Armstrong. Or, again, Armstrong's being legged makes the contingent truth that something has legs true. But his being legged doesn't make it true that it is possible that nothing has legs. Hilary Clinton's making a bid for the presidency of the United States of America makes the contingent truth that a woman has made a bid for the presidency of the United States true. It doesn't, though, make it true that it is possible that no woman has made a bid for the presidency of the United States. I take these and many other counterexamples to show that the Possibility principle is false.

Strictly speaking, these are counterexamples to the conjunction of the Possibility principle with the relevance (or aboutness) desideratum, not counterexamples to the Possibility principle alone. One could drop the relevance requirement rather than the Possibility principle if one so desired. Armstrong does not so desire, though. He writes, 'I do not want to retreat to the view that these necessary truths, unlike contingent truths, lack truthmakers or, what is practically equivalent, that all have the very same truthmakers' [2004: 98]. And even if one were to part ways with Armstrong here and abandon the relevance requirement, doing so would make the Possibility principle unnecessary. To see why, consider the following.

The Possibility principle is intended to provide relevant truthmakers. If relevance didn't matter, any existing thing would be a truthmaker for truths of mere possibility. If one does not rein in a truthmaker principle with a relevance condition, all modal truths would have trivial truthmakers. We wouldn't need the Possibility principle - the Entailment principle would suffice. Dropping the relevance requirement makes the Possibility principle irrelevant.

An objector may note that each of my examples requires use of the Entailment principle. ${ }^{15}$ For instance, the atom example requires that that Armstrong is composed of $N$ atoms (where $\mathrm{N}$ is greater than fifty) entails* that something is composed of more than fifty atoms. Why can't Armstrong deny this particular use of the Entailment principle, claiming that that Armstrong is composed of $N$ atoms is not relevant to the truth that something is composed of more than fifty atoms? Such a denial would save the Possibility principle from this particular counterexample.

I think that this is a good suggestion for Armstrong, but I don't think it will save the Possibility principle. For, even if there might be reason to think that this response works well for the number of atoms counterexample, it doesn't work nearly as well for the other counterexamples. Consider: is it

\footnotetext{
${ }^{15}$ I owe this objection to Joe Salerno.
} 
really true that the truth that Armstrong has legs is irrelevant to the truth that something has legs? This is just an existential generalization. Likewise, doesn't that Hilary Clinton has made a bid for the presidency of the United States relevantly entail that a woman has made a bid for the presidency of the United States?

Elsewhere Armstrong himself uses similar existential generalizations to provide truthmakers for truths. We don't, for instance, need a general state of affairs of something existing for it to be true that something exists. Rather, each individual thing makes it true that something exists [2004: 8991]. But this is just an application of the Entailment principle, and, in fact, it is wholly similar to my use of the Entailment principle concerning Armstrong's having legs. Also see Armstrong's discussion of the truthmakers for the truth that at least one contingent being exists. The truthmaker for such a claim isn't the general state of affairs of at least one contingent thing's existing; rather, each contingent thing is a minimal truthmaker for this truth. Again, we see Armstrong using the Entailment principle to provide truthmakers for existential generalizations in the same way I use the Entailment principle in my counterexamples.

Without delving into Armstrong's account of truthmakers for necessary truths, we can see that it, too, relies on the Possibility principle, and hence it is subject to the same difficulties as his account of truthmakers for truths of mere possibility. Armstrong writes of a benefit of his theory of truthmakers for necessary truths [2000: 158]:

[T] he real pay-off of the point that necessary truths require no more than truthmakers for the possibility of the existence of their terms lies in the result, if it is a result, that I reached earlier in this paper. Provided that the terms are always contingent beings, provided that there are no necessary beings, then we can appeal to the truthmakers already proposed for truths that assert the possibility of some contingency.

The result that Armstrong refers to here is the Possibility principle.

Since Armstrong's account of truthmakers for both truths of possibility and truths of necessity requires the Possibility principle, and the Possibility principle should be rejected, Armstrong's account of truthmakers for modal truths ought to be rejected as well. It may be that giants aren't required for modal metaphysics, but Armstrong's Possibility principle is not the giant slayer he intends it to be; it is no David. ${ }^{16}$

The University of Saint Thomas (Minnesota)

Received: March 2009

Revised: July 2009

\footnotetext{
${ }^{16}$ This paper benefited from comments by or discussion with Scott Berman, Marian David, William Demsar, Trent Dougherty, Michael Foland, Jon Jacobs, Faith Glavey Pawl, John Putz, Joe Salerno, Kevin Sharpe, Eleonore Stump, Kevin Timpe, René van Woudenberg, and Bill Wood, and the audience at the 2008 Central States Philosophy Conference, where I presented this paper. Part of the writing of this paper was made possible by a Dissertation Fellowship at the Center for Philosophy of Religion at Notre Dame.
} 


\section{REFERENCES}

Alward, Peter 2004. Review of David Armstrong's Truth and Truthmakers, Disputatio 17/1: 74-8.

Armstrong, David 1997. A World of States of Affairs, Cambridge: Cambridge University Press.

Armstrong, David 2000. Difficult Cases in the Theory of Truthmaking, Monist 83/1: 150-60.

Armstrong, David 2003. Truthmakers for Modal Truths, in Real Metaphysics, ed. H. Lillehammer and G. Rodriguez-Pereyra, London: Routledge: 12-24.

Armstrong, David 2004. Truth and Truthmakers, Cambridge: Cambridge University Press.

Armstrong, David 2005. Reply to Simons and Mumford, Australasian Journal of Philosophy 83/2: 271-6.

Armstrong, David 2006a. Reply to Efird and Stoneham, Australasian Journal of Philosophy 84/2: 281-3.

Armstrong, David 2006b. Reply to Heil, Australasian Journal of Philosophy 84/2: 245-7.

Armstrong, David 2007. Truthmakers for Negative Truths and for Truths of Mere Possibility, in Metaphysics and Truthmakers, ed. J. Monnoyer, Frankfurt: Ontos Verlag: 99-104.

Beebee, Helen and Julian Dodd, eds, 2005. Truthmakers: The Contemporary Debate, Oxford: Oxford University Press.

Bostock, Simon 2005. Review of David Armstrong's Truth and Truthmakers, Philosophical Books 46/4: 369-70.

Cameron, J. R. 2005. Review of David Armstrong's Truth and Truthmakers, Philosophy 80: 285-9.

Hochberg, Herbert 2006. Review of David Armstrong's Truth and Truthmakers, Metaphysica: International Journal for Ontology and Metaphysics 7/2: 187-92.

Kalhat, Javier 2008. A Critique of Armstrong's Truthmaking Account of Possibility, Acta Analytica 23/2: 161-76.

Keller, Philipp 2007. A World of Truthmakers, in Metaphysics and Truthmakers, ed. J. Monnoyer, Frankfurt: Ontos Verlag: 105-56.

Lewis, David 1992. Critical notice of D. M. Armstrong, A Combinatorial Theory of Possibility, Australasian Journal of Philosophy 70/2: 211-24.

Lewis, David 2001a. Truthmaking and Difference-Making, Noûs 35/4: 602-15.

Lewis, David 2001b. On the Plurality of Worlds, Cambridge: Blackwell Publishing.

Lewis, David 2005. Things qua Truthmakers, in Real Metaphysics, ed. H. Lillehammer and G. RodriguezPereyra, London: Routledge: 25-38.

McDaniel, Kristopher 2005. Review of David Armstrong's Truth and Truthmakers, Notre Dame Philosophical Reviews 8.

Merricks, Trenton 2007. Truth and Ontology, Oxford: Oxford University Press.

Monnoyer, Jean-Maurice, ed., 2007. Metaphysics and Truthmakers. Frankfurt: Ontos Verlag.

Mumford, Stephen 2005. The True and the False, Australasian Journal of Philosophy 83/2: 263-9.

Plantinga, Alvin 1974. The Nature of Necessity, Oxford: Oxford University Press.

Simons, Peter 2005. Negatives, Numbers, and Necessity: Some Worries About Armstrong's Version of Truthmaking, Australasian Journal of Philosophy 83/2: 253-61.

Tallant, Jonathan 2005. Review of David Armstrong's Truth and Truthmakers, Philosophical Writings 29: $85-7$. 